\title{
RESTITUTION IN THE CZECH REPUBLIC: \\ PROBLEMS AND PRAGUE-NOSIS
}

\section{INTRODUCTION}

After the Velvet Revolution in November 1989, the first freely elected government of Czechoslovakia decided that to implement a free market economy it was necessary to quickly transfer state-owned properties and enterprises into private hands. ${ }^{1}$ The newly-elected political reformers believed that a free-market economy was based on private ownership of property, and they promptly began to explore means by which property could be shifted from state to private ownership. ${ }^{2}$ The government saw the restitution of property to its original owners as a means not only to speed up the privatization process, but also a prerequisite for developing a free-market economy. ${ }^{3}$ However, after implementing restitution laws, the government realized that these laws had quite the opposite effect. Although restitution laws initially slowed economic reform and privatization, ${ }^{4}$ they in fact created a sense that some justice had been achieved ${ }^{5}$ to compensate for the inexorable property confiscations and nationalization programs implemented by the communist Czechoslovak government. ${ }^{6}$ The restitution laws also reintroduced the Czechs to concepts of private ownership and other market-oriented legal principles and practices. ${ }^{7}$

This Comment points out how these factors contributed to a newfound trust in Czech legal and democratic systems that has yielded increased economic growth and democratic reform. The Czechs will take more economic risks as they face fewer legal risks, and foreign investment should increase due to increased confidence in the Czech legal system. Although restitution laws initially slowed the privatization process, they should produce quicker reform and a more stable free-market economy and democracy for the Czechs.

Also analyzed are the effects of Czech restitution laws on the privatization process, and economic and democratic reform in the Czech Republic. This Comment is divided into four subject areas: (1) an historical account of how property and industry of the former Czechoslovakia was confiscated and

1. Vojtech Cepl, A Note on the Restitution of Property in Post-Communist Czechoslovakia, 7 J. COMMUNIST STUDIES 367 (1991).

2. Id.

3. Id. at 368 .

4. Diane Francis, Who Owns What in Eastern Europe?, FInANCIAL Post, Sept. 8, 1993, at 11, available in WESTLAW, INT-NEWS Database.

5. Deborah Scroggins, Untangling Communism; Atlanta'sEasternEuropean Émigrés Trying to Reclaim Ancestral Lands, THE ATLANTA JOURNAL AND CONSTITUTION, Aug. 19, 1991, at A2.

6. Czechs to Return Seized Property, N.Y. TIMES, Feb. 26, 1991, at A10.

7. Cheryl W. Gray, The Legal Framework for Private Sector Activity in the Czech and Siovak Federal Republic, Working Papers, The World Bank, Introduction, Nov. 1992. 
nationalized; (2) a summary of actual restitution and privatization laws; (3) how restitution laws initially retarded privatization, economic growth, and democratic reform; (4) why the restitution laws, even after causing a slow start to reform, will result in the Czech Republic being able to proceed with privatization and more stable economic and democratic reforms.

On January 1, 1993, the former Czechoslovakia split to become the Czech Republic and Slovakia.This Comment only covers the effects of restitution laws on the Czech Republic even though the laws were enacted under the government of the former Czechoslovakia. The reason for focusing solely on the Czech Republic is that the economy, political landscape, infrastructure, and geographic situation of the two newly-formed democracies differ, and the effects that these factors will have on the future of each country will not be the same.

\section{HISTORICAL BACKGROUND}

On October 28, 1918, in the aftermath of the First World War, Czechoslovakia became a modern nation state and enjoyed twenty years of relative peace and prosperity. ${ }^{8}$ In 1938 , in the face of Nazi expansion, Chamberlain, Daladier, Hitler, and Mussolini met in Munich and formulated the infamous Munich Agreement. This agreement allowed Hitler to annex the German speaking Sudetenland region of Czechoslovakia. Soon thereafter, the French and British informed Czechoslovakia that if they acted alone in resisting Hitler, such resistance would be considered a provocation of war. ${ }^{9}$ Czechoslovakia remained compliant, and less than six months after the Munich agreement, Nazi troops marched on Prague. ${ }^{10}$

In 1944, with the end of the Second World War in sight, the leaders of the United States, Great Britain, and the Soviet Union met in Yalta to determine the fate of postwar Europe. Czechoslovakia was one of the dividing points. The leaders decided that the Soviets would liberate Prague; consequently, Czechoslovakia fell under the Soviet sphere of influence, which ultimately led to the 1948 communist takeover of Czechoslovakia." From 1945 to 1948 , the Czechoslovak (or Benes) government, acting within the scope of the 1920 Czechoslovak constitution, confiscated much of the land of the Sudeten Germans and Hungarian minority, who had collaborated or sympathized with the Nazis during the Second World War. ${ }^{12}$ Many of the large industries

8. R.W. Seton-Watson, A History OF THE Czechs AND Slovaks 310 (1943).

9. A.H. Hermann, A HistORY OF THE CZECHS 266 (1975).

10. Czechoslovakia: CrossroAdS AND CRISES 89 (Norman Stone and Eduard Strouhal eds., 1989).

11. Herman, supra note 9, at 268.

12. Cepl, supra note 1 , at 69. 
and businesses also were nationalized during these years. ${ }^{13}$

In February 1948, Soviet-backed communists took over Czechoslovakia ${ }^{14}$ and started the mass confiscation of private property and nationalization of industry. ${ }^{15}$ The final result of the Communist takeover was that Czechoslovakia endured the most intensive and comprehensive private property confiscation and business and industry nationalization of any of the Soviet bloc countries, excluding the Soviet Union. The communist government gave little or no consideration for confiscated property; "[s]eizures were often carried out illegally, even under the laws passed by the [c]ommunists. Owners of factories or farms were expelled from their houses on short notice, and sometimes sentenced at summary trials to hard labor, apparently for the sole crime of belonging to the "enemy class." 16 Many of the other former Soviet bloc countries were able to maintain some level of private property and small businesses, whereas not even "mom-and-pop shops" remained in Czechoslovakia. ${ }^{17}$ This extensive property and industry nationalization put Czechoslovakia at a severe disadvantage for reform in comparison to other former Soviet-bloc countries that broke free from communism in the revolutions of 1989.

\section{ThE PRIVATZZATION AND RESTITUTION LAWS}

The Czech privatization plan has been controversial. Essentially, it is a three-step process. "The first step is the re-privatization [restitution] of shops and enterprises to their original owners; the second step is the privatization of small industries; and the final step will involve selling or breaking up the

13. Jeffrey J. Renzulli, Comment, Claims of U.S. Nationals Under the RestitutionLaws of Czechoslovakia, 15 B.C. INT'L \& COMP. L. REV. 165, 166 (1992).

14. Stone and Strouhal supra note 10, at 162.

15. Renzulli, supra note 13 , at 167.

16. See supra note 6, at A10. Deputy Prime Minister Pavel Rychetsky said in an interview, "Persecutions and confiscations were more intensive here than in neighboring countries, with the exception of the Soviet Union. There is greater moral awareness here about the appropriateness of returning property."

17. R.C. Longworth, Czechoslovakia's Rush to Reform Becomes a Perilous Free-for-all, Chicago Tribune, Oct. 22, 1991, at 1C. "Unlike Poland or Hungary, Czechoslovakia had no private business - not even mom-and-pop shops - before the Communist government fell in 1989. Now the reform government wants to privatize businesses, big and small, and it wants to do it quickly." 
large state conglomerates." 18 The supporters of this three step process envisioned a rapid privatization process that would radically transform the Czech economy similar to the Polish "shock treatment economics" program in $1989 .{ }^{19}$ As one top governmental official remarked, "You can't understand the scope of the challenge and opportunity until you realize that here we don't own anything other than our toothbrushes. ${ }^{120}$

Three main restitution laws were enacted in the years immediately following the Velvet Revolution. These laws are as follows: (1) the Small Restitution Law, "Act on Relieving the Consequences of Certain Property Injuries", (2) the Large Restitution Law, "Extra-Judicial Act", and (3) the Land Law, "Adjustment of Ownership Rights of Land and Other Agricultural Property." The speed of the privatization process depends upon how issues involving restitution are handled. ${ }^{22}$ Czechoslovakia was the first former communist country to enact such a sweeping law on restitution of property that was either confiscated or nationalized by the former communist regime. ${ }^{23}$ If the Czech Republic proves its sincerity about upholding property rights, foreigners may be encouraged to invest in or buy the remaining land and industry. Foreign investment is necessary to speed up the economic growth of this poor, formerly communist country. ${ }^{24}$

\section{A. The Small Restitution Law}

The Federal Assembly of the Czech and Slovak Federal Republic enacted the Law on the Mitigation of the Consequences of Certain Property Losses on October 2, $1990 .^{25}$ This law, also known as the

18. Richard M. Phillips \& Marian G. Dent, PrivatizingEastern Europe: A Challenge for the Nineties, PRACTICING LAW INSTTTUTE, April 15-16, 1991, available in WESTLAW, JLR Database.

19. Id.

20. Richard S. Gruner, Of Czechoslovakiaand Ourselves: Essential Legal Supports for a Free Market Economy, 15 HASTINGS INT'L \& COMP. L. REV. 33 (1991).

21. Ivan Svitek et al., Investment 1992/93: A Current Guide to Business Laws, Regulations and Contracts in Czechoslovakia, 84-87 (Cara Morris \& Mark Baker eds., 1992).

22. Michael L. Neff, Comment, Eastern Europe's Policy of Restitution of Property in the 1990's, 10 DICK. J. INT'L L. 357, 358 (1992).

23. See supra note 6, at A10.

24. Neff, supra note 22 , at 370 .

25. Law on the Mitigation of the Consequences of Certain Property Losses, of October 2, 1990, Law No. 403/1990 Coll. of Laws (Zakon o zmirnni nasledk nekterych majetkovych krivd) [hereinafter Small Restitution Law], 2 Central \& Eastern European Legal Materials: Czechoslovakia, Privatization and Entrepreneurship, $\S 19$ (Transnational Juris Publications, Inc., U.S., Graham \& Trotman, U.K., Kluwer Academic Publishers, The Netherlands). 
Small Restitution Law, went into effect on November 1, 1990. Claimants were given six months from this date to file a restitution claim. ${ }^{26}$ This law applies to citizens who lost property pursuant to certain governmental regulations on nationalization enacted between 1955 and $1959 .{ }^{27}$

The Small Restitution Law limits restitution to the natural person or private legal entity from whom the government confiscated the property. ${ }^{28}$ If the original owner is dead or declared to be dead, a rightful heir can claim the property. ${ }^{29}$ The claimant bears the burden of demonstrating how and when the expropriation occurred and that he was the victim or victim's rightful heir. ${ }^{30}$ If the claimant is a foreign national, he must prove that he had not previously settled his claim through an interstate property agreement. ${ }^{31}$ This law does not apply to property acquired after October 1, 1990, and commercial companies and enterprises with foreign ownership participation are precluded

26. Id. art. $19(1)$.

27. Id. art. 1. The specific governmental regulations are as follows:

The law refers to the consequences of property losses caused to natural persons and private legal entities by the abrogation of ownership rights to real or movable property under governmental decree no. 15/1959 Coll. of laws on measures relating to certain property used by organizations in the socialist sector, under Law no. 71/1959 Coll. of laws on measures relating to certain private residential property, and through nationalization carried out on the basis of the decisions of certain ministries issued after 1955 and pertaining to the nationalization laws of 1948. Abrogation of ownership rights under this law is also understood to mean the transfer of ownership rights on the basis of a purchase contract pursuant to para. 1 and 2 of Art. 4 of government decree no. 15/1959 Sb.

28. Id. art. 2. These are the only governmental decrees under which a person is eligible for restitution under the small restitution law. Id.

29. Id. art. 3. (Eligible heirs, in order of entitlement, are a child, spouse, parent, or sibling of the original owner as well as testamentary heirs living at the time the law went into effect.)

30. Id. art. 3.

31. Id. art. 20. See generallyCzechoslovakian Claims Settlement Act of 1981, Pub. L. No. 97-127, 95 Stat. 1675(1981). See also note 13, at 174-77. The following is an example of such an agreement:

In 1981, the two govermments signed the U.S.-Czechoslovak Claims Settlement Agreement (Claims Agreement). Under the terms of the Claims Agreement, the U.S. government withdrew its objection to the release of 18,400 kilograms of gold belonging to Czechoslovakia which had been held since World War II by the Tripartite Commission for the Restitution of Monetary Gold. In return, the Communist government paid $\$ 81.5$ million to the U.S. government in satisfaction of claims of nationals of the United States whose property rights in Czechoslovakia were impaired by nationalization measures in place from the end of World War II until 1981.

If a claim is settled under such an agreement, then the claim is ineligible for restitution. Id. 
altogether. ${ }^{32}$

Upon written request from the "entitled person" (hereinafter obligee), an organization is obliged to complete the following: promptly restore the property to the obligee; with the obligee draw up an agreement on the restitution of the property; and upon the mutual settlement of claims, register the agreement with a notary public. If the organization fails to comply with any of these obligations, the obligee can seek satisfaction of his claims in court. ${ }^{33}$

Natural in kind restitution of the property in its present condition is normally awarded; however, pecuniary compensation is given by the state in some cases. ${ }^{34}$ Cases where financial restitution is awarded include: (1) when the building was significantly improved or deteriorated, the owner receives the value of the original building and land; ${ }^{35}$ (2) when the building was destroyed but nothing was built on the site, the owner receives the value of the land and building; ${ }^{36}$ or (3) when the building was torn down and a new structure was erected, the owner receives the value of the original building and land. ${ }^{37}$ If the claimant receives natural restitution he is not allowed to evict the persons currently occupying residential or non-residential premises. Legal regulations as to the use of apartments and subletting of non-residential premises shall also remain in force. ${ }^{38}$

\section{B. The Large Restitution Law}

The Federal Assembly of the Czech and Slovak Federal Republic enacted the Law on Extrajudicial Rehabilitation on February 21, 1991. ${ }^{39}$ This law became effective on April, 1, 1991. ${ }^{40}$ Claimants had six months from this date to file claims. ${ }^{41}$ This law "concerns the redressing

32. See Small Restitution Law, supra note 25 , art. 4.

33. Id. art. 5 .

34. Id. art. $10(1),(2)$.

35. Id. art. 10(3).

36. Id. art. $14(1)$.

37. Id. art. 14(1).

38. Id. art. 12.

39. Law on Extrajudicial Rehabilitation, of February 21, 1991 Law No. 87/1991 Coll. of Laws (Zakon o mimosoudnich rehabilitacich) [hereinafter Large Restitution Law], 2 Central \& Eastern European Legal Materials: Czechoslovakia, Privatization and Entrepreneurship, $\$ 21$, (Transnational Juris Publications, Inc., U.S., Graham \& Trotman, U.K., Kluwer Academic Publishers, The Netherlands).

40. Id. $\$ 35$.

41. Svitek, supra note 21 , at 85 . 
of the results of certain property and other injustices arising from legal actions and rulings in both the civil and labor legal spheres...." Compensable injustices must have arisen between February 25, 1948 and January 1, 1990. ${ }^{42}$ Some of these "other injustices" include people who were imprisoned, served in labor camps, had their jobs taken away from them illegally, or were not permitted to complete their education. ${ }^{43}$ This law does not apply to property that was nationalized between 1945 and 1948 under the Benes government. Therefore, Sudeten Germans and ethnic Hungarians who collaborated with the Nazis are not eligible for restitution for any property that was confiscated during this time period. A large portion of industrial and church property that was nationalized during these postwar years is also ineligible for restitution under this law. ${ }^{44}$

The Large Restitution Law also encompasses the restitution claims of foreign nationals. In order to prevent émigrés from bringing claims and not making any use of the property they received, the obligee must be a physical person having his citizenship and place of permanent residence in the Czech and Slovak Federal Republic. ${ }^{45}$ If the person who was dispossessed of property by the state is dead (or is proclaimed dead), his property can be claimed by a rightful heir, provided that the heir is a citizen of and has his place of permanent residence in the Czech and Slovak Federal Republic. ${ }^{46}$ Émigrés from Czechoslovakia who had become foreign nationals could bring a restitution claim only if they returned to Czechoslovakia and reclaimed Czechoslovak citizenship and permanent residence in Czechoslovakia. ${ }^{47}$ This restitution law precludes foreign nationals or Czechoslovak citizens who permanently reside abroad from bringing claims of restitution. ${ }^{48}$ In the Large

42. See Large Restitution Law, supra note $39, \S 1$.

43. Id. $\S \S 14(2), 16,17,18$.

44. Id.

45. Id. § 3(1).

46. Id. $\$ 3(2)$ (Eligible heirs, in order of entitlement, are a child, spouse, parent, or sibling of the original owner.)

47. Id.

48. Renzulli, supra note 13, at 166-67. The 1928 U.S. - Czech Treaty on Naturalization is an example of how foreign nationals could qualify for restitution under this law.

On July 16, 1928, the United States and Czechoslovakia signed a treaty covering naturalization issues (Treaty on Naturalization). The Czechoslovak government entered into the Treaty on Naturalization in order to inter alia, prevent its nationals from temporarily emigrating to the United States in order to avoid military duty. The Treaty on Naturalization has assumed importance today, however, because the recently-adopted Czechoslovak restitution program allows $\mathrm{Czechoslovak}$ nationals who emigrated to return 
Restitution Law, there is no equivalent to article 20 of the Small Restitution Law, which states that foreign nationals who have settled their claims according to an interstate property agreement are not eligible for restitution. ${ }^{49}$

Also, the Large Restitution Law imposes many duties and obligations on parties involved in the restitution of property. The "obliged person" (hereinafter obligor) is the state or legal person in possession of the property sought by the obligee. Assets held by private corporations or joint ventures not obtained from a legal person on or after October 1, 1990, were not restored. Property held by foreign states was not restored either. ${ }^{50}$ The obligor was required to relinquish an article at the written request of the obligee and upon a showing of his right to transfer of the article and demonstration of the manner in which it became property of the state. The claimant was required to assert his claim within six months from the law's effective date or the right lapsed. If the obligor failed to comply with the request, the obligee could pursue the claim in court, provided it was done within one year from the law's effective date. ${ }^{51}$ Upon the transfer of real estate, the obligee acquired all the rights and duties of a lessor, including any contracts or agreements vested in the property. If the obligee and the tenant could not come to agreement regarding the amount and conditions of rent payment, it would be set by the appropriate state administration. Even after a property was transferred to the obligee, if such property was used for certain socially beneficial purposes, it may be required to continue

to Czechoslovakia permanently and reclaim lost property. Article I of the Treaty on Naturalization states that nationals of Czechoslovakia who are naturalized in the United States automatically lose their Czech nationality. Nationals of either country who are naturalized while their country of origin is at war, however, do not lose their original nationality. In addition, article III of the Treaty on Naturalization provides that individuals who return to their country of origin intending to remain permanent residents shall lose citizenship previously acquired by naturalization. According to the treaty, individuals intend to remain permanent residents in their country of origin if they return and reside more than two years in that country. The Treaty on Naturalization, ratified by the U.S. Senate on January 26, 1929, was still good law as of October 15, 1991.

49. Such treaties can impose unfair or unreasonable requirements on foreign nationals who would otherwise bring restitution claims. Id. (Citations Omitted). See generallysupra note 39, see also supra note 25.

50. See supra note $39, \S 4$.

51. Id. $\& 5(4)$. 
that use for up to ten years. ${ }^{52}$ If possible, restitution in kind is to be made with the property in the condition existing on the day the written request for its surrender was received by the obligor. ${ }^{53}$ Monetary compensation for the return of real estate is given under the same conditions as it is in the Small Restitution Law. ${ }^{54}$

\section{The Land Law}

The Federal Assembly passed the Land Law on May 21, 1991. This law outlines the rights and duties of present owners, original owners, users, and renters of land, as well as the role of the state in regulating the rights of both owners and tenants of land. The law went into effect on July 1, 1991, and eligible claimants were required to file claims before December $31,1992 .{ }^{55}$

This law affected only land, buildings, and other assets confiscated between February 25, 1948, and January 1, 1990. It not only covers agricultural and forest land, residential and utility buildings, but also covers agricultural property belonging to the original agricultural settlements. $^{56}$ Furthermore, only 150 hectares (370 acres) of land or forest may be restored to any one owner. However, there is a proposed amendment to the Land Law that would provide for restitution of more than 150 hectares of land or forest to a single owner. ${ }^{57}$

The person seeking restitution must be the original owner. If the original owner is not living, then his property can be claimed by a rightful heir, such as a child, spouse, parent, or siblings. As in the Large Restitution Law, the heir must also be a Czechoslovak citizen and reside in the country. Persons other than the owner of the property may use land on a contract basis with the owner or the Land Fund. Goods produced on the land are the property of the owner. Furthermore, only citizens and residents of Czechoslovakia are eligible for restored assets

52. Id. $\S 12$. Such socially beneficial purposes include: the activity of diplomatic and consular missions; the carrying out of health and social services; the purposes of education; the carrying out of cultural activity; and the work of rehabilitation and/or employment physically disabled persons. Id.

53. Id. $\S 7(1)$.

54. Id. $\$ \S 7,8$; see also supra notes 34-37 and accompanying text.

55. Svitek, supra note 21, at 86-87, No. 229/1991 Coll. of Laws, "Adjustment of Ownership Rights of Land and Other Agricultural Property", (Zakon o uprave vlastnickych vztahu $k$ pude a jinemu zemedelskemu majetku), [hereinafter Land Law].

56. Id.

57. Id. at 87 . 
and land ownership is not transferable to foreigners. ${ }^{58}$

If land assets cannot be physically returned, the claimant receives compensation. The compensation received for the unreturned land is paid by the state. Furthermore, any compensation for unreturned assets is paid by the institution holding the asset at the time of its alteration or destruction. If the original owner is unknown, the Land Fund is entitled to rent the real estate until a claimant steps forward. Compensation will also be paid for all living and non-living inventory taken into a cooperative or confiscated in the time period covered by the law. Owners of cooperatives are not allowed to transfer their assets to citizens or other organizations if the transfer does not comply with the Law on Transformation of Cooperatives passed on December 21, 1991.59

\section{The Jewish Restitution Law}

The Czech government recently enacted a special restitution law for Jews. This law was enacted because of the special difficulties involved in finding eligible claimants. Jewish property was originally confiscated by Germans after 1939, but was not claimed because the Czech Jewish community was virtually eliminated by the Nazi holocaust. Jewish property is being given to surviving Jews so that the rightful owners or their heirs may be located. If heirs cannot be found, the Jewish community keeps the properties. ${ }^{60}$ The return of this property to Jewish organizations in no way contravenes the eligibility date for receiving restitution, which is February 1948, when the Communist Party seized power. ${ }^{61}$

\section{E. The Pre-1948 Restitution Law}

The Czech Parliament enacted a fourth restitution law in April of 1992. This law calls for the return of land confiscated from ethnic Germans and Hungarians after the Second World War, as long as the former owners remained in the country and regained their citizenship. ${ }^{62}$

58. Id.

59. Id.

60. Francis, supra note 4, at 11.

61. Legislators to Propose Laws on Church Property, CTK - Business News, Mar. 4, 1993, at 8, available in WESTLAW, INT-NEWS Database.

62. Gray, supra note 7 , at 5 . 


\section{F. The Small Privatization Law}

The Federal Assembly of the Czech and Slovak Federative Republic passed the Act on the Transfer of State Ownership of Certain Property to Other Legal or Natural Persons, on October $25,1990,{ }^{63}$ which took effect on December 1, $1990 .^{64}$ This law deals with the selling of small to medium sized businesses that were state owned and financed through either state budgets, state contributions, or national committees and had their right of management on or before November $1,1990 .^{65}$ Both movable and immovable assets of a "business unit" that are not involved with agricultural production are subject to transfer of ownership. ${ }^{66}$ This law does not apply to business units with foreign ownership or control, nor does it apply to property that has had a timely claim filed against it under the Small Restitution Law. ${ }^{67}$ However, because the statute of limitations of the Small Restitution Law runs at the same time as the Small Privatization Law, a person can bring a restitution claim against a property that has already been purchased through privatization. Persons who were Czechoslovak citizens on or after February 25, 1948, are eligible for ownership of these business units. ${ }^{68}$

The state agency of the Czech or Slovak Republic organizes and authorizes a public auction in which it awards title to the business unit to the person (Czechoslovak citizen) who submits the highest bid. ${ }^{69}$ Properties not successfully auctioned off in the first round are auctioned in a second round by authorized agencies of the Republics. During this second auction of a property, foreign investors may participate and acquire property rights to business units. ${ }^{70}$ The highest bidder in either auction must pay the full auction price into a special account of the authorized agency of the Republic within thirty days. ${ }^{71}$ If the highest

63. Act on the Transfer of State Ownership of Certain Property to Other Legal or Natural Persons of October 25, 1990, Act No. 427/1990, Coll. of Laws (Zakon o prevodech vlastnictvi statu $\mathbf{k}$ nekterym vecem na jine pravnicke nebo fyzicke osoby) [hereinafter Small Scale Privatization Law], 2 Central \& Eastern European Legal Materials: Czechoslovakia, Privatization and Entrepreneurship, $\$ 22$ (Transnational Juris Publications, Inc., U.S.; Graham \& Trotman, U.K.; Kluwer Academic Publishers, The Netherlands).

64. Id. art. 27.

65. Id. art. 1.

66. Id. art. 2(1).

67. Id. art. 2(2).

68. Id. art. 3.

69. Id. art. 4.

70. Id. art. 13.

71. Id. art. 11(1). 
bidder fails to pay the full auction price within the allotted time period, then the transfer of ownership is nullified. ${ }^{72}$ This law is intended to transfer state owned property into private hands and generate needed capital for further reform programs quickly.

\section{G. The Large Privatization Law}

The Federal Assembly of the Czech and Slovak Federative Republic passed the Act on the Conditions of Transfer of State Property to Other Persons on February 26, $1991^{73}$ which took effect on April 1, 1991. ${ }^{74}$ This law defines circumstances under which the state ownership of certain enterprises, mainly medium to large sized businesses, have their right of management transferred to Czech, foreign juristic, or natural persons. ${ }^{75}$ This law precludes from privatization any property that is subject to certain constitutional enactments, legislation, or the Small Restitution Law. ${ }^{76}$ Privatization of property must accord with the approved privatization project for that enterprise or the state proprietary participation in entrepreneurial activity. ${ }^{77}$ The founder, to whom the enterprise's privatization project proposal is submitted, is responsible for establishing the terms of the proposal. ${ }^{78}$ After the founder evaluates all privatization proposals, if he is a federal central authority of state administration he submits them to the Federal Ministry of Finance; if not, he submits them to the competent authority of state administration of the Republic. ${ }^{79}$ The Federal Minister of Finance or the competent authority of the state administration then must approve and publish the privatization proposal. ${ }^{80}$

Once a privatization proposal has been approved, it becomes part of the Federal Fund of National Property (hereinafter Fund), which

72. Id. art 11(2).

73. Act on the Conditions of Transfer of State Property to Other Persons, of February 26, 1991, Law No. 92/1992, Coll. of Laws (Zakon o podminkach prevodu majetku statu na jine osoby) [hereinafter Large Privatization Law], 2 Central \& Eastern European Legal Materials: Czechoslovakia, Privatization and Entrepreneurship, $\$ 22$ (Transnational Juris Publications, Inc., U.S., Graham \& Trotman, U.K., Kluwer Academic Publishers, The Netherlands).

74. Id. art. 49.

75. Id. art. 1(1). (including state banking institutes, state insurance companies and other state organizations, as well as foreign trade companies).

76. Id. art. 3.

77. Id. art. 5 .

78. Id. art. 7.

79. Id. art. 8.

80. Id. art. $10(1)(\mathrm{a})$. 
has been established to direct the transfer of ownership. ${ }^{81}$ Similar funds also exist for the Czech and Slovak Republics respectively. The Fund will take possession of the properties and uses them to form new companies, promote joint stock companies, or sell the company or parts of the company in public auctions to individual buyers. ${ }^{82}$

The investment coupon (or voucher) is another method of privatization incorporated within this law. Any Czechoslovak citizen who is 18 years of age at the date of issuance of the coupons and a permanent resident of Czechoslovakia is eligible to receive investment coupons for a nominal price. ${ }^{83}$ The coupons can be used to purchase shares of any approved joint-stock company or participation in approved commercial companies. ${ }^{84}$ The investment coupon is "a security (consolidated paper) in name giving the right to purchase shares specified for sale against coupons. The coupon shall be untransferable and the rights attached to the same can be transferred only to heirs. The coupon cannot be amortized. ${ }^{85}$ Thus, voucher coupons are designed to restrict alienation to foreigners and to keep the Czechs from being exploited.

\section{How the REstitution LAWS INITIALLy SLOWED DOWN PRIVATIZATION AND ECONOMIC REFORM}

\section{A. The Fear of Unknown Restitution Claims}

Initially, the restitution laws caused a slower privatization process and economic growth rate than anticipated. The restitution program was much more extensive and expensive than planned. Some estimates put the total cost of restitution as high as $\$ 10.7$ billion $^{86}$ and the estimated time of completion for the restitution process between two to ten years. ${ }^{87}$ Czechoslovak Minister of Finance, Vaclav Klaus, while

81. Id. art. 27.

82. Id. art. 28.

83. Id. art. $23,24$.

84. Id. art. 25.

85. Id. art. 22.

86. Prague Votes to Return NationalizedProperty, ChICAGo TRIBUNE, Feb. 22, 1991, at 1C. (Finance Minister Vaclav Klaus was quoted as telling parliament, "[a]s much as $\$ 10.7$ billion worth of property nationalized by the communists after they took power in 1948 will be turned back to private owners under the so-called restitution bill approved Thursday....")

87. Privatization in Czechoslovakia on Time, but Delays likely, Officials Say, BNA INT. FIN. DAILY, Mar. 5, 1991. (Josef Danco of the Slovak planning commission stated that the government's willingness to deal with restitution would further complicate the privatization process. Danco stated. "the procedure could take two to three years, or maybe five to ten years."), 
commenting on the financial aspect of restitution in February 1991, stated, "it is very complicated, as we do not know the exact number of people the restitution will apply to."88

One of the reasons the restitution claims will slow privatization and economic reform is that they are de facto liens. Restitution claims must be resolved before business and other properties can be privatized. ${ }^{89}$ Consequently, restitution laws created uncertainty regarding property ownership, ${ }^{90}$ which in turn causes delays in the process of approving privatization projects $^{91}$ and, ultimately, economic reform. ${ }^{92}$

Restitution laws also handicapped the privatization process because of the sheer number of claims made. The effect of numerous restitution claims in agriculture, for example, almost caused privatization to come to a complete stop. ${ }^{93}$ The Minister of Agriculture, Josef Lux, stated that 228,179 restitution claims totaling thirty-four billion koruny ${ }^{94}$ were made for agricultural property. ${ }^{95}$ Czech agriculture officials projected that eighty percent of the agricultural restitution claims would be cleared by the end of $1993 .^{96}$

Perhaps the biggest problem resulting from the implementation of restitution laws has been awarding restitution in kind (the actual property or land being given back) in lieu of monetary or voucher restitution. Restitution in kind creates many problems such as moving

88. Czechoslovak Federal Assembly Passes a Bill on Extra-Judicial Rehabilitations, CTK Ecoservice, Feb. 22, 1991, at 12, availablein WESTLAW, INT-NEWS Database, (Klaus made this comment while addressing the Federal Assembly on February 21, 1991).

89. Francis, supra note 4, at 11.

90. Official Sees End of State Ownership of Businesses, CTK Ecoservice, May 27, 1991, at 4, available in WESTLAW, INT-NEWS Database.

91. PrivatizationProjects Considered by Slovak Ministry, CTK Ecoservice, Jan. 10, 1992, at 6, available in WESTLAW, INT-NEWS Database.

92. Privatizationin Czechoslovakia: Learningto Walk, THE ECONOMIST, Feb. 2, 1991, at 71 .

93. Deputy Minister on the Privatization Process, CTK Ecoservice, June 29, 1993, at 3, available in WESTLAW, INT-NEWS Database. Deputy Minister for Administration of National Property, Jaroslav Jurecka, said "that the original expectation that restitution would be the fastest way for privatizing has not come true. In agriculture, for instance, restitution has almost stopped the privatization process. A plan to fix this has been worked out, but a certain amount of time has been lost." Id.

94. (USD \$1. = 27-31 Czech Crowns (koruny) as of summer, 1993).

95. Agriculture Ministeron Progress of Privatizationin Farming and Food Industries, BBC MONITORING SERVICE - EASTERN EUROPE, June 10, 1993, available in WESTLAW, INT-NEWS Database.

96. EC Experts and Agriculture Ministry Want Regular Communication, CTK National News Wire, Oct. 20, 1993, available in WESTLAW, INT-NEWS Database. 
or compensating current tenants when the rightful owner obtains title to the property, the expanse of time involved in proving and settling claims, and the conflict created when claims arise against property that has already been privatized. ${ }^{97}$

Tremendous controversy surrounded both the passage and implementation of the restitution laws because all allow for restitution in kind. ${ }^{98}$

The restitution laws also produce a general disincentive to foreign investors against investing in the Czech Republic. The Czech restitution laws deter investment because they preempt privatization laws. Thus, the management of a business must search the records of the registry of deeds to ascertain whether there was a pre-1948 private owner before commencing a privatization project. If there would be a private owner who would be entitled to file a claim, then the privatization project should be delayed until the statute of limitations for filing the claim has expired. ${ }^{99}$

Czech citizens and foreign nationals alike are hesitant to invest in companies or to buy land or businesses because of the risk of an unknown restitution claim being brought against the property. ${ }^{100}$ Prior to the split, Czechoslovaks were afraid to invest their voucher points or capital, and foreign investors were afraid to invest their hard currency and advanced technology. Both are desperately needed for the weak Czech economy to survive. The Czech Republic needs well-defined property rights that will protect foreign and domestic investors from losing their property through restitution. Even other former communist countries dealing with the restitution issue express the desire to avoid the experience of Czechoslovakia. Polish Finance Minister, Leszek Balcerowicz said, "It's time we learn from someone else's mistakes, not our own."101

97. Ten Slovak Parties and Movements Oppose Restitution in Kind, CTK National News Wire, Feb. 12, 1991, available in WESTLAW, INT-NEWS Database.

98. Mary Battiata, Issue of Seized Property Divides Poles; Ex-Owners' Prospects Founder in Financial Straits of the New Rule, THE WASHINGTON Post, May 5 1991, at A35.

99. Vratislav Pechota, Privatization and Foreign Investment in Czechoslovakia: The Legal Dimension, 24 VAND. J. TRANS. LAW 305, 312 (1991).

100. 60 Food Processing Enterprises Await Privatization, CTK Ecoservice, July 28, 1993, at 8, available in WESTLAW, INT-NEWS Database. "Enterprises like the Pelhrimov and Strakonice breweries in South Bohemia cannot be privatized due to restitution disputes. Both of the brewers and the famous Karlovy Vary (Carlsbad) producer of Becherovka liquor have made restitution claims on the breweries."

101. Battiata, supra note 98, at A35. (referring to the Czechoslovak restitution program). 


\section{B. The Problem of Unclear Title}

Title to property in the Czech Republic is unclear at best and nonexistent at worst. The communists failed to maintain accurate title registries to properties. Some land registries were not even kept after 1964, and the government deliberately destroyed others. The result of this non-practice has been that it is very difficult and time consuming for a claimant to prove he is the rightful owner or heir to the asset in question, and there is more than one claimant in some cases. For some, enduring this bureaucratic nightmare is not worth the effort. ${ }^{102}$

Restitution claims brought under the land law could be made until December 31, 1992. However, claimants' challenges to the present possessors' denials of the claims will most likely extend the pendency of claims for quite some time, thus delaying the time when all restitution claims will be settled. ${ }^{103}$ The communist regime further clouded title to property by transferring agricultural land between different enterprises without any consideration of former ownership. The prior neglect in keeping title records has made title investigation virtually useless and resulted in investors having to "wait and see" if anyone would show up to claim the land. ${ }^{104}$

Due to the problem of unclear titles existing in Czechoslovakia, the restitution claims took much more time to process than planned. This results in slowing the progress of privatization and increasing the burden on the judiciary. ${ }^{105}$ In addition, title insurance was nonexistent in Czechoslovakia and caused further loss of incentive for investment. Clear and reliable property rights must be established if the Czech Republic is to progress into a viable democracy with a free-market economy.

\section{Increased Burden on the Judiciary}

The restitution laws have placed a great burden on the judiciary. Because Czechoslovakia has one of the highest rates of nationalization of the former communist countries, the number of restitution claims

102. Scroggins, supra note 5, at A2.

103. Henry W. Lavine et al., Czech and Slovak Privatization: Issues and Approaches for WesternInvestors, Practicing Law Institute Mar. 18, 1992, available in WESTLAW, JLR Database.

104. Milan Ganik et al., Czech Reform Has Investors Guessing, 14 NAT'L L.J. 17, 20

105. See infra. 
has been great, and probably too extensive for a poor country like the Czech Republic. ${ }^{106}$ The extensive Czech restitution program has put great stress on the already overburdened and underpaid judicial system. $^{107}$ Although many claimants under the Large and Small Restitution Laws have settled, numerous disputes over restitution persist in the courts. ${ }^{108}$ Section 5 (4) of the Large Restitution Law states that if the person obliged to return the property to the person entitled to it does not do so within the time period allotted, then the entitled person can pursue a claim in court if done within one year from the effective date of the law. ${ }^{109}$ These disputes, often between competing claimants or between former owners and current tenants, are jamming the court system because none of these collateral disputes are required to be dealt with extrajudicially. ${ }^{110}$ Simply put, the added weight of collateral and derivative restitution claims on the judicial system has slowed the privatization process at a time when the Czech judicial system is too weak to try to satisfactorily complete the task of resolving additional restitution disputes.

106. Pechota, supra note 99, at 308 . Comparing the extent of nationalization in former communist countries Pechota stated,

In contrast to Polish and East German Socialism, which tolerated, to a certain extent, small businesses on the manufacturing and service sectors, the Czechoslovak socialist 'perfectionists' nationalized or 'persuaded' private owners to transfer practically all businesses to the state or to a cooperative. The 1960 Czechoslovak Constitution celebrated this feat as an astounding victory for socialism.

107. This gives some idea of how extensive a nationalization program Czechoslovakia was subjected to and infers that it will make the restitution process that much more difficult. Lloyd N. Cutler \& Herman Schwartz, Constitutional Reform in Czechoslovakia: E Duobus Unum?, 58 U. CHI. L. REV. 511 , 539 n.72 (1991). "The Czech Republic alone is said to be short at least 330 judges. One hundred were dismissed after November 1989, and another 120 left voluntarily, with only 115 new judges appointed to replace them. Unfortunately, the salary and social status of judges are both very low." (emphasis added). Id.

108. Gray, supra note 7 , at 24 . Gray presents numerical data as to how overburdened the judicial system actually is,

Asin other CEE countries, judicial institutions in the CSFR are ill-prepared to cope with the rapidly emerging challenges of a market economy. The plethora of new legislation in the past 2 years has bred many new types of disputes never before seen by this generation of judges and lawyers. In 1991, some 121,000 commercial cases were filed in the Czech Republic (48,000 in Prague alone) and some 60,000 in the Slovak Republic. That number is expected to jump significantly higher in 1992 as new restitution cases enter the courts and as the moratorium on bankruptcy claims is lifted.

Id.

109. This demonstrates that the judiciary is currently overloaded and that the restitution claims will place a further burden on the system. See supra note 39, art. 5 . 
The extensive Czech restitution program has yielded increased litigation and court costs when the money could have been better spent elsewhere. Estimates have placed the cost of the restitution process near $\$ 11$ billion. ${ }^{111}$ Moreover, while legislators debated over what form the restitution laws should take, the privatization process was delayed for several months. ${ }^{112}$

These problems have resulted in undue amounts of time and money being wasted, whereas more efficient deployment of these valuable resources could be used to advance the Czech Republic's privatization and economic reform.

\section{Other Problems Resulting From Restitution In Kind}

Where returned property is not in the same condition as when confiscated, monetary compensation can be awarded. Monetary compensation is limited to $\$ 1,000$ in cash, with the balance paid in vouchers or bonds for investment in new privatization projects. ${ }^{113}$ However, these vouchers and bonds have not been a very sound way to invest, given the state of the fledgling Czech economy, where businesses and industries are not certain to withstand the transformation into a free market economy.

Many of the properties are returned in poor condition or beyond repair from years of neglect. Thus, many entitled to such properties are hesitant to take them because of the cost of restoration and improvement. Although foreigners may have the capital and technology to improve and make efficient use of the property, most Czech citizens

111. Peter S. Green, Czechoslovak Restitution Could Cost \$II Billion, UPI, Feb. 21, 1991, available in LEXIS, Nexis Library, MAJ-PAP File. "The government said it could cost as much as $\$ 11$ billion to make restitution for businesses and other real estate that were confiscated and privatized in $\mathbf{4 2}$ years of communism."

112. Edward P. Lazear, Politics Thwarts Reform, CHRISTIAN SCIENCE MONITOR, April 16,1991 , at 18. Lazear points out how the debate over the form of the restitution laws actually slowed down the reform process:

Reforms have been slowed by debates that pit one interest group against another. In Czechoslovakia, privatization was held up for a few months while legislators argued about the form that restitution of property to its historical owners would take. Eventually, a compromise was struck, but the details of capital distribution are still not decided.

Id.

113. If the issue of how the restitution laws were to be implemented had been settled quicker, then the privatization process would not have been held up as long. See supra note 6 , at Al0. 
do not. George Lobkowicz, a European banker who had never been to Czechoslovakia, recently became a Czech prince, and his family became one of the country's biggest landowners as a result of the restitution laws. But, instant riches are not all they are cracked up to be. Lobkowicz says, "It's a nightmare, properties are in horrid shape and many are beyond repair. One cannot selectively ask for restitution. If you want the great artworks back in a castle that's falling apart, you must take both or get neither. There are other problems. I have 2,500 acres of vineyards and know absolutely nothing about winemaking, so I've had to bring in consultants from Germany."114

This issue of privatizing agricultural lands also caused heated debate amongst reformers. The controversy over the transfer of agricultural land to private owners was seeded in the rare success of the collective and state farms. "The industrial regimen that the communists inflicted on agriculture may have driven the Soviet Union into famine and disorder, but it fostered efficiency in Hungary and Czechoslovakia and bestowed both with a rare economic success." 115

Under the pre-collective system, a farmer in Czechoslovakia worked from sunrise to sunset seven days a week; a day off was unimaginable. Under the Communist regime, farmers on collectives rotated on eight hour shifts, so everyone got a two-day weekend in addition to having vacations, holidays, and sick leave. The collective farmers in the Czech Republic only earn about as much as Czech factory workers. AntiCommunist activists maintain that the farmers are taken advantage of by communists struggling to keep their power and ideology in the countryside, but most farmers do not want to change. ${ }^{116}$ Also, many claims involve parcels of land that are in the middle of huge fields that are now part of collective farms. ${ }^{117}$

Another problem is that many people are interested only in obtaining land, but have no plans for its future use. ${ }^{118}$ After all of the restitution claims settle and land returns to the rightful owners, the collective and state farms fulfilling many important economic functions may no longer exist. However, letting properties or agricultural lands remain idle while

114. Diane Francis, Restitution of Property to Pre-1948 Owners Can Be Expensive, FIN. Post, Aug. 27, 1992, at 11.

115. Carol Williams, Czech, Hungarian Collectives Are Rare Success Story--and Apt to Stay; Agriculture: A Plan to Return Farmlands Taken Away 40 Years Ago Draws Little Interest from Today's Workers, Los ANGELES TIMES, Feb. 24, 1991, at D8.

116. Id.

117. Josef Burger, Politics of Restitution in Czechoslovakia, 26 EAST EUROPEAN QUARTERLY 485, 493 (1993).

118. Minister of Agriculture Comments on Government Agrarian Program, CTK Ecoservice, Nov. 16, 1992, at 3, available in WESTLAW, INT-NEWS Database. 
destroying a collective farm system that functions well is an inefficient allocation of resources, a policy that the Czech economy can ill afford.

Protective rent and tenant restrictions have created yet another problem. The civil code of 1992 covering owner/tenant relations states that an owner cannot evict a tenant unless the tenant fails to pay rent, or if the owner or tenant of a ground level shop in the same building wants to move into one of the flats. When a landlord legally evicts a tenant, the legal foundation for deciding who is responsible for finding adequate substitute accommodations for the evicted tenant is not clear. ${ }^{119}$

Protective rent controls place owners in a precarious situation by not allowing rent increases to keep pace with maintenance costs. For example, in 1992 a residential apartment of approximately 860 square feet could be rented for $\$ 64$ per year, with the occupants protected by favorable tenancy laws.

One letter to the editor documented the economics of despair in the case of a solidly built brick row of apartments (15 units) in a highly desirable area, which under current rent levels could produce a total rent income of $\$ 5,500$ per year. The property required $\$ 43,000$ in immediate repairs to prevent further deterioration. On the real estate market the building is valued at $\$ 300,000$, though as an investment it cannot yield a return commensurate to this price. ${ }^{120}$

Rent controls have also kept residential rents exceedingly low compared to rates found in a free market system. Rents have doubled, but they are still unnaturally low. ${ }^{121}$ The Czech government has found itself in a dilemma; it is unjust to restrict the owner's right of free-alienation, yet it is also against public policy to displace long time tenants.

\section{E. Who Should be Entitled to Restitution and Where Should the Line Be Drawn?}

Much debate centers around which groups can bring restitution claims and where the line in time should be drawn. Should Sudeten Germans or ethnic Hungarians who collaborated with the Nazis in World War II receive restitution? Should persons whose land or industries the Benes government nationalized before 1948 receive compensation?

119. Svitek, supra note 21 , at 81 .

120. Burger, supra note 117, at 490-91.

121. Gray, supra note 7 , at 7. 
Should former communists (who claim that commercial entities were constructed with the voluntary contributions of its members, rather than with state assets) be entitled to restitution?

Recent restitution laws have dealt with some of these questions, but many remain unanswered. The Jewish Restitution Law will provide for restitution of property owned by Jews if it was owned in 1947. The Pre-1948 Restitution Law is essentially the same as the Jewish Restitution Law but applies to gentiles. This law excludes any claims by Jews or the two million ethnic Germans who comprised the economic elite in pre-war Czechoslovakia simply because the line in time determining eligibility does not reach that far back. A Czech legislator explained that, "It would be politically impossible to give property back to those ethnic Germans because many controlled the economy and many also collaborated with the Nazis. The Germans in Czechoslovakia were kicked out after liberation in 1944 and their lands confiscated."122 Are there political motivations behind the restitution laws? One independent Czech paper "Lidove Noviny" says,

[t]hat those who fight for such restitution taken to the point of absurdity merely satisfy their doubtful political ambitions. History does not know restitution of such an extent. Not even Louis XVIII resorted to something like that in the Bourbon Restoration. Poland and Hungary are silent about restitution and they know well why. Only we are perhaps poor enough to be able to afford it. Because the rich ones cannot. It adds that those who want to go before February 1948 cannot ignore the property of Slovak Jews, transferred Germans and, last but not least, the land reform of 1919 and the expropriations after the battle of White Mountain in 1620. How far is there to go to absurdity? ${ }^{123}$

\section{F. Some Suggestions As To How Restitution Could Be Handled}

Instead of focusing on restitution in kind, other forms of compensation such as financial or voucher coupons should be awarded. Thus, those seeking to buy or invest in property and businesses would not have to worry about a potential restitution claim being brought against them. This would allow the privatization process to move ahead

122. Francis, supra note 4 , at 12.

123. Papers Warn Against Too Extensive Return of Property, CTK National News Wire, Feb. 12, 1991, available in LEXIS, Nexis Library, MAJ-PAP File. 
unimpeded and result in greater economic growth, strength, and stability for the Czech Republic. Perhaps a comprehensive compensation fund established at the outset for awarding money, voucher, or stock restitution would alleviate many of the problems associated with restitution in kind. As for agricultural lands, the Czechs should follow Hungary's example of giving privatization coupons that can be exchanged for land only if the land is intended for farming. Otherwise, coupons could be used to buy stock in industrial enterprises. ${ }^{124}$

There could also be more incentives given for foreign nationals to seek out and bring restitution claims. This could be done by offering joint-venture options, investment, tax, or customs incentives. Czech Restitution Laws made it difficult for foreign nationals to instigate and prevail on restitution claims. For example, U.S. nationals of Czech origin were required to submit several items to the Czechoslovak Embassy in Washington before they were allowed to present any evidence of ownership to the current occupiers of the property. Among these items were:

[a]n application for temporary or permanent residency in Czechoslovakia, four photographs exactly passport sized, and a letter specifically explaining one's life story with specific explanation of one's financial assets, education, training, skills, and occupational experience. These claimants were also required to submit a detailed family tree, describing all relatives, their dates of birth, citizenships, and their occupations, and a notarized letter from a person who agreed to assume responsibility for the claimant's housing and medical expenses when the claimant returned to Czechoslovakia. Finally, if the claimant had emigrated from Czechoslovakia because of crimes that had purportedly been committed, the claimant was required to submit evidence of the punishment given by the communist government and a request that such punishment be stricken from the government's records. ${ }^{125}$

Even after these items had been submitted to the Czechoslovak Embassy, they were still subject to the approval by the Czechoslovak Government. Approval of these submissions could take an unduly long amount of time and result in the claimant missing the statute of limitations for filing restitution claims. Applications for residency alone could take three months or longer to be processed. After applications are approved, 
the claimant must certify possession of good title to the property. If the claimant is unable to obtain the title deed, a local lawyer might be required to search the land records to confirm the status of the property. ${ }^{126}$ Had the Czech Restitution laws been more accommodating to foreign nationals, there would have been an increase in foreign investment, capital, and advanced technology.

Before this comment went to print, the Czech Constitutional Court deleted two parts of the Large Restitution Law. Involved are the provisions that make eligibility for restitution conditional on permanent residence in Czechoslovakia or the Czech Republic and the six-month window in which claimants must have filed. ${ }^{127}$ The Court's decision, which takes effect in November 1994, enables persons with Czech citizenship, who have been ineligible until now, to file restitution claims for the first time. Permanent residents of Czechoslovakia or the Czech Republic who failed to bring restitution claims are not subject to the court's decision. ${ }^{128}$ However, it should also be noted that some government officials believe that the Constitutional Court has overstepped its powers by deciding to delete these provisions of the Large Restitution Law. ${ }^{129}$ There are many political considerations impacting the Court's decision, but hopefully the Czechs will decide against prolonging the restitution process or they may see the fruits of their progressive reforms spoil or go unharvested.

The many difficulties and uncertainties present for foreign nationals eligible for restitution actually discourage foreign investment. In fact,

126. Id.

127. ConstitutionalCourt Extends Deadline for RestitutionClaims, BBC MONITORING SERVICE - EASTERN EUROPE, July 14, 1994, available in WESTLAW, INT-NEWS Database. According to Vojen Gurtler, the justice-rapporteur in the case,

The Law on extra-judicial rehabilitations was aimed at redressing the most serious property and other wrongs, from which emigrants could not be excluded. The condition of permanent residence in the country ignored the freedom of movement and residence, embeded ( $\mathrm{sic}$ ) in the Charter of Basic Human Rights and Freedoms and also granted by the Czech Constitution, and thus contravened these documents. The court also confirmed the reservation of the deputies that the several-month deadline set for potential claimants to start action, were "inappropriately short' and discriminated against the citizens from abroad, mainly overseas. They may not have learnt (sic) about the restitution possibility in the time set by the law, and thus were prevented from raising their justifiable demands.

Id.

128. Id.

129. Ministers Say Constitutional Court Oversteps its Competence, BBC MONITORING SERVICE - EASTERN EUROPE, July 16, 1994, available in WESTLAW, INT-NEWS Database. 
most émigrés who took up citizenship in other countries that offered refuge from communist Czechoslovakia, "have spent decades building new lives for themselves and now consider these countries to be their homes. As they are getting older, they are unwilling to return to Czechoslovakia for another new start in a country with a very uncertain future."130

Capital, technology, and the experience of foreign investors are needed for the Czech Republic to achieve rapid economic reform. The Czech government has begun working with foreign nationals, especially those who have proven business records and hard currency, to convert their returned properties and businesses into capital producing entities. These foreign nationals bring expertise on functioning within a capitalist system, a concept foreign to many Czechs. Perhaps the most famous of these agreements was struck with the Toronto shoe magnate, Thomas Bata.

Some of the most closely watched negotiations to privatize a state enterprise have involved the Svit shoe-manufacturing factory in Zlin, an industrial center of 90,000 in central Czechoslovakia. Founded at the turn of the century, the company was the property of the Bata family, which moved to Canada from Czechoslovakia in 1939, well before the interim postwar government confiscated it in October, 1934. After the Communists fell, Toronto millionaire Thomas Bata, 76, the chairman of Bata Ltd., renewed his claim as the rightful owner of the Zlin factory and demanded restitution. Czechoslovakia's restitution laws, enacted last June, entitle former owners of small businesses such as barbershops or bakeries seized by the Communists to reclaim their properties. But so far, the government has not applied the same rules to large, potentially profitable enterprises.

After more than a year of tough negotiations, Bata and government officials reached an initial compromise in October. The agreement, which goes into effect this month, has created Bata CSFR, a $\$ 30$ million joint venture initially compromising 30 retail stores and one small shoe factory. The 30 stores, including the flagship store on Prague's Wenceslas Square, will be allowed to distribute a maximum of 20 percent of the shoes sold in the country. Under the terms of the agreement, Bata Ltd. will have a 70 percent stake in the operation, as well as an option to acquire the Czechoslovakian government's 30 
percent stake over the next five years. The Bata company will manage Bata CSFR, as well as providing marketing and technological expertise, extensive employee training and other improvements. ${ }^{131}$

These kind of compromises are not only beneficial to the Czech economy and privatization process, but also to the restored owner. ${ }^{132}$ More of these mutually beneficial compromises will allow the Czech Republic to move ahead with free-market and economic reform at a quicker pace.

A final alternative is to move forward with privatization and economic reform without regard to the transgressions of the communist system. During the debate of the restitution laws, then Finance Minister Vaclav Klaus said, "The whole issue of restitution is extremely difficult, perhaps impossible. I don't know if there's an answer. I might almost be inclined to regard Communism as a natural disaster and not give anything back to anybody." 133 However, dealing with restitution in this manner could have resulted in dire consequences. Extensive nationalization of private property in Czechoslovakia has created a prevailing sense of indignation amongst the populace. Thus, in the former Czechoslovakia's unique situation, the restitution laws also served an important moral purpose. Without some sense of renumeration for the crimes of the communists, there may have been a movement by the people to seek justice for these crimes in another manner. Because Czechoslovakia has dealt with this issue, Czechoslovakia may end up being years ahead of its formerly communist neighbors in the privatization and economic reform process.

\section{LONG TERM EFFECTS OF THE RESTITUTION LAWS}

\section{A. Initial Slowdown of Reforms v. Rapid Future Reform}

Reformation and privatization for the Czech Republic were initially slow, but as the restitution process ends, the Czechs can look forward to rapid future reform. Democracy, capitalism, and the privatization process can now move forward without the fear of new restitution claims,

131. Barbara Wickens, Post-Communist Chaos (Investing in Eastern Europe), MACLEAN's, Jan. 20, 1992, at 36 .

132. Barbara Wickens, Picking Up The Pieces; Thomas Bata Gives Czech Capitalism A Boost, MaCleaN's, July 9, 1990, at 35.

133. Lawrence Joseph, Prague 's SpringInto Capitalism, THE N.Y. TIMES, Dec. 2, 1990 , $\S 6$, pt. 2, at 20 . 
laws, and the accompanying political turmoil. A main reason for enacting the restitution laws was to address the moral outrage of the Czech people against the communist regime. Former Finance Minister, Vaclav Klaus, said, "We are convinced that if there is restitution, the price tag is not important. It is a moral issue." ${ }^{134}$ This issue has been dealt with at the cost of slowing privatization and economic reform. However, providing the Czechs with some sense of justice for the egregious wrongs committed by the communists appears to be a necessary step to growing the cause of democracy and economic reform. Not taking this step might have resulted in a much worse long range outcome for the Czechs.

Although the restitution laws initially slowed privatization and economic reform, these laws successfully introduced the concepts of private property and ownership, which were previously unknown to most Czechs. These laws also familiarized the Czechs with marketoriented legal principles and practices. ${ }^{135}$ A solid understanding of these concepts is essential to transforming a state-run economy into a free-market economy. The Czechs should now be prepared to make a quicker transformation. Moreover, some long-term results of the restitution laws include clearing up cloudy title, better defining property rights, and establishing real property law, all of which will be relied upon by future generations. ${ }^{136}$

\section{B. Other Factors Contributing to Successful Economic and Democratic Reform in the Czech Republic.}

There are several other underlying factors that should contribute to successful economic and democratic development in the Czech Republic. First, Czechoslovakia had an established industrial tradition, a highly skilled labor force, and a stable infrastructure. ${ }^{137}$ Czechoslova-

134. Green, supra note 111. (Klaus made this comment while speaking at a parliament session that was explaining restitution laws).

135. Gray, supra note 7 , at introduction.

136. CzechoslovakiaMoves Toward PrivatizationFor Small Retail Businesses, Service Sector, INT'L TRADE REPORT, Oct. 17, 1990, available in LEXIS, MAJ-PAP File.

137. World Bank Economic Surveyof Czechoslovakia,CTK Ecoservice, Nov. 22, 1991, at 15, available in WESTLAW, INT-NEWS Database.

"The country's labor force of about 7.8 million is well-educated and highly skilled . . . . Czechoslovakia was the richest of the "successor states" that emerged from the Austro-Hungarian Empire following World War I. Its economy had not been damaged during the war, and the country contained over two-thirds of the industry of the old empire, but only one-fourth of its population and one-fifth of its area. . . Although more economically 
kia also performed well economically, when compared to neighbors who had centrally planned economies. ${ }^{138}$ These factors should compensate for the initially slower privatization process and lead to economic and democratic success for the country. Additionally, three per cent of all privatization receipts now go to a compensation fund for restitution claims, ${ }^{139}$ and many companies reserve an additional three per cent of their shares as a part of their privatization projects. ${ }^{140}$ These funds should defray the future costs of restitution and help mitigate many future privatization problems.

Economic indicators also denote a bright future for Czechoslovakia. The Czech Republic has a very low foreign debt as compared to other Eastern European countries, and has built up a good reputation among Western investors. ${ }^{141}$ This is due to political stability, a well-educated workforce, and low inflation. ${ }^{142}$ The Czech Republic also has a low total debt as a percentage of Gross Domestic Product (GDP), no budget

and institutionally isolated than its neighbors, Czechoslovakia's performance has compared well with other formerly centrally planned economies".

Id.

138. Czechoslovakia: Big Deals Begin Despite Legal Confusion, IMC Business Communications M \& A EUROPE, Nov/Dec. 1990, at 60, availablein LEXIS, MAJ-PAPFile.

"Czechoslovakia is the dark horse in Eastem Europe's race toward free-market economies. It has great potential in the long run, thanks to its established industrial tradition, highly skilled labor force and relatively strong infastructural base. But it is a slow starter, lagging behind Hungary in privatization and behind Poland in economic reforms".

Id.

139. Pechota, supra note 99 , at 314 ; see also notes 81 and 82.

The Large-Scale Privatization Act creates a new agency, the Federal Fund of National Property (Federal Fund), and entrusts the task of carrying out the privatization program to the Federal Fund and to the Czech Fund of National Property and the Slovak Fund of National Property. The latter two funds will be established by the legislatures of the respective republics. The Federal Fund will assume the ownership of any federal property to be privatized, whereas the funds of the republics will become the owners of all republican assets chosen for privatization.

The Federal Fund is a legal entity separate from the state. The property of the Federal Fund cannot be used by the state to generate revenues or to meet budgetary needs; the property can be utilized only for privatization and for satisfying restitution claims.

140. Lavine et al., supra note 103.

141. Czechoslovakia Needs Foreign Capital and Know-How, Finance Official Says, BNA INT'L TRADE DAILY, Mar. 27, 1991, availablein LEXIS, MAJ-PAPFile. Pavol Parizek, chief international finance of the Czechoslovak Finance Ministry said that, "Czechoslovakia had an advantage over other East European countries in having little foreign debt, totaling $\$ 7.5$ billion at the end of the last year, and no domestic debt." Id.

142. CzechPrivatization, Blood Sweat and Capitalism, THE ECONOMIST, June 19, 1993, at 71 . 
deficit as a percentage of GDP and an extremely low long-term interest rate. ${ }^{143}$ Additionally, the Czech Republic has the lowest unemployment rate in all of Europe at 2.7 percent. ${ }^{144}$

The geographic location of the Czech Republic is beneficial as well and must not be overlooked. A good portion of the Czech Republic borders Germany and Austria, and Prague is further west than Vienna. This gives the Czech Republic a strategic advantage in foreign trade and investment over other Eastern European countries. The similarity of German, Austrian, and Czech Cultures should aid in communication and understanding of customs, which are important to foreign trade. Furthermore, an increase in exports and imports, a great decrease in the cost of production, and a stable Czech Crown (Koruny) also point to successful reform for the Czech Republic.

The Czech Republic has enjoyed much political and social stability in recent years, brought about by its economic reform programs. The exclusion of any political party with less than five percent of the vote has spared the Czech parliament from the fragmentation that has afflicted Poland. ${ }^{145}$ The aforementioned factors make it evident that the Czech Republic is in a unique position to embrace economic recovery and democratic reform.

\section{CONCLUSION}

Although the restitution laws resulted in an initial slowing of the privatization process and economic and democratic reform, the Czechs will ultimately be stronger for squarely addressing the restitution issue and its attendant problems. The Czechs will see their country blossom into one of the world's strongest new free-market economies, where real property law and democracy truly exist for the first time in over forty years. Though the restitution laws could not fully compensate people for the lives, careers, and happiness taken away during the four decades of Soviet domination, at least some sense of justice has been served. The new laws have created confidence in the legal system and democratic process, which will result in increased Czech and foreign national investment. With fewer economic risks and a more stable legal and political system, the Czech Republic should become a leading nation

143. Eastern Europe: The Old World's New World, THE ECONOMIST, Mar. 13, 1993, at 21 .

144. See supra note 142 , at 71 .

145. Klaus Can Well Be Satisfied With Reforms -- ANSA, CTK National News Wire, Oct. 20, 1993, available in LEXIS, NEXIS Library, CTK File. 
in Eastern Europe, and, possibly, one of the first former communist countries to become a member of the European Community. The restitution laws brighten the future of the Czech Republic by serving the dual purpose of forestalling future problems while alleviating the pain associated with the old ones.

Richard W. Crowder

* J.D. Candidate, May 1995, I.U. School of Law-Indianapolis; B.A., Goshen College. The author thanks his wife, Rachelle, for her encouragement and support during this endeavor. The author also thanks his editor, Jeffrey $D$. Heck, for his insightful critique. 
